\title{
Pragmatic implications of head and dependent marking ${ }^{1}$
}

\author{
Carlotta Viti \\ University of Zurich
}

Head marking and dependent marking are considered to be major parameters of syntactic diversity, and are traditionally related to the geographical distribution of languages. Some areas such as Standard Average European favor dependent marking, while head marking is preferred in the New World. However, head and dependent marking may also occur in the same language, either in different domains of grammar or - more interestingly - in competing constructions that are used to convey the same propositional content. In Italian, for example, the choice of head or dependent marking is strongly conditioned by pragmatic factors. Head marking mainly expresses topical information, while the focus is usually conveyed by dependent marking. Moreover, head marking is preferably used in the spoken informal language, while dependent marking prevails in the written formal register. This indicates that structurally different language types may be similar in the organization of pragmatic information.

Keywords: head marking, dependent marking, topic, focus, spoken language, Italian

\footnotetext{
${ }^{1}$ This paper was presented at the Circolo Linguistico Fiorentino (June 30th 2006) and at the 39th Annual Meeting (Bremen, August 30th-September 2nd 2006) of the Societas Linguistica Europaea, dealing with 'Relativism and Universalism in languages'. I express my gratitude to Winfried Boeder, Alberto Nocentini, and OnoPremper Yoshiko for stimulating questions and remarks. Thanks are also due to a number of anonymous referees of Folia Linguistica for useful feedback.
}

Folia Linguistica 43/2 (2009), 463-485.

ISSN 0165-4004, E-ISSN 1614-7308 (C) Mouton de Gruyter - Societas Linguistica Europaea DOI: FLIN.2009.013 


\section{Introduction}

The parameter of head and dependent marking, identified in Nichols (1986) and refined in Cysouw (2002), captures a way in which languages differ strikingly in terms of syntax. As Nichols put it, "syntactic relations can be morphologically marked either on the head of a constituent, or on the dependent. [...] The syntactic relation is one and the same, but the principles for marking that relation are diametrically opposed [...]" (p. 57). Languages are usually consistent in marking grammatical relations either on the head or on the dependent of a constituent. Cross-linguistically, there is a polar dependent-marking type, which includes the Indo-European stock, and a polar head-marking type, which is typical of the languages of the Americas. In the Caucasus, an area of high linguistic diversity, Chechen and Abkhaz exemplify dependent marking and head marking, respectively. In the noun phrase, Chechen marks the possessive relation on the dependent possessor (1), while Abkhaz marks the same relation on the head possessee (3). In the clause, the relation between the predicate and its arguments is marked on the dependent arguments in Chechen (2), but on the predicate head in Abkhaz (4).

Chechen (North-East Caucasian; Nichols 1986: 60, 108)

(1) de:-n a:x̌̌a

father-GEN money

'father's money'

(2) su stag-a zudčun-na kni:ga-Ø j-elira

DEM.OBL person-ERG woman-DAT book-NOM $j$-gave

'the man gave the woman the book'

Abkhaz (North-West Caucasian; Nichols 1986: 60, 108)

(3) $\quad \grave{a}-\check{c}^{\prime} k^{\circ}$ วn $\boldsymbol{y} \boldsymbol{\partial}-y^{\circ} n \boldsymbol{\partial}$

the-boy his-house

'the boy's house'

(4) $\quad a-x a ̀ c ' a \quad a-p \hbar^{\circ} \partial s \quad a-\check{s}^{\circ} q^{\circ} \partial s \quad \boldsymbol{O}$-lo-y-te-yt

the-man the-woman the-book it-to.her-he-gave-FINITE

'the man gave the woman the book'

However, head and dependent marking may also occur in the same language. In this case, it is more common for a head-marked construction to be found in an otherwise dependent-marking language than the other way round. This is especially the case in the domain of agreement. The Indo- 
European languages, for example, mark subject agreement on the verb, i.e. on the head of the clause, although they encode possession, as well as various relations of arguments and adjuncts, on the dependent. Even Chechen, which Nichols presents as a prototypical dependent-marking language, exhibits one trait of head marking, in that it has a small group of prefixed verbs that agree in gender and number with an absolutive marked noun (Nichols 1986: 71).

As is well-known, agreement markers often arise through the grammaticalization of anaphoric pronouns in topic-shift constructions, according to which a left-dislocation such as The man, he came over time becomes a single clause with verb-subject agreement such as The man hecame (Givón 1976). Givón demonstrates that verbal agreement is especially triggered by subjects, indirect objects, and definite or human objects, because these relations refer to topical roles, which are more likely to occur in dislocations. A discourse is rarely about inanimate referents, so syntactic relations such as locative, manner, instrument, etc. represent rather untypical triggers of agreement. The topical constructions underlying agreement patterns occur especially in the non-standard variety of a language, as the studies of Ashby (1977, 1982), Lambrecht (1981), and Matthews (1989), among others, show for Non-Standard French.

This suggests that the syntactic dichotomy between head and dependent marking may also be relevant to information structure and to sociolinguistic considerations, as we will see below in data drawn from Colloquial Italian. Apparently, the categorical use that some languages make of either head or dependent marking represents only the extreme case of a continuum of variation that is conditioned by the speaker's perspective of the event.

\section{Romance cliticization as an instance of head marking}

The question of the topical function of head marking arises particularly when one considers that cross-linguistically head-marked constructions are built on pronouns (Nichols 1986: 76-77; 1992: 77-82). In the Abkhaz clause in (4), for example, the syntactic function of the extraposed noun phrases corresponding to 'the man', 'the woman' and 'the book' is specified by the string of proclitic pronouns 'it', 'to her' and 'he' leaning on the verb 'gave'. Pronouns (and particularly clitic pronouns) entail that the referent is predictable, and tend to occur in long chains. Therefore, they do not only 
imply given information, but also persisting, important information. Economy is the motivation of the association between pronouns and head marking, which is clear, for example, in the Uralic and in the Semitic stocks, and which holds true for both possessive and adpositional phrases. Since pronouns belong to a closed class, they have a greater chance of being combined with the head. The phonologically reduced form of pronouns favours such a combination. Although head marking is not ascribed to the reconstructed Proto-Indo-European (Nichols 1986, 1992; Helmbrecht 2001; Cysouw 2002), such phenomenon may appear in the daughter languages through borrowing or independent innovation. For example, in Hittite head marking occurs with inalienable possession. In Irish, head marking occurs with adpositions plus pronouns. In the Romance languages, head marking occurs in cliticization, whereby dependency is signaled by an unstressed pronominal form leaning on the nominal or verbal head.

Clitics may be included among manifestations of head marking to the extent that their position is determined by the syntactic principle of adjacency to the verbal head, rather than by the prosodic principle of second position in the clause. Accordingly, Romance clitics can be more properly considered head-marked structures than Slavic clitics. Romance clitics are always adjacent to the verb, whether or not they occupy the second position in the clause (5). Conversely, Slavic clitics are bound to the Wackernagel position, whether or not they are adjacent to the verb (6). In this case, phonology is at least as important as syntax for the distribution of clitics.

Italian

(5) Giovanni la vede ora. / La vede ora Giovanni. / Ora Giovanni la vede. 'John sees her now.'

Serbo-Croatian

(6) Ivan je vìdī sada. / *Je vìd̄ sada Ivan. / *Sada Ivan je vìdī. 'John sees her now.'

Romance clitics may be considered to be markers of agreement (independently of the degree of grammaticalization that such agreement may have in different Romance languages), because they form a phonological unit with the verb; they have a fixed order; they cannot appear in isolation; they are obligatory, that is, they cannot be anaphorically deleted; they cannot be contrastively stressed; they cannot be modified, conjoined, relativized upon or followed by appositions, etc. (cf. Lambrecht 1981: 17ff). Romance clitics may form different constructions. They may occur instead of a noun 
phrase, as in the clause Giovanni la vede ora 'John sees her now' in (5), where the Italian clitic pronoun la replaces a feminine noun phrase. This is what Bossong (1981) calls conjugation complémentaire of clitics. Alternatively, clitics may be used in addition to a noun phrase (called conjugation supplémentaire in Bossong's terms, or clitic doubling), as in the Italian examples (7) and (8), which represent a 'left-dislocation' and a 'rightdislocation' respectively. ${ }^{2}$

(7) Lemele le prendo dopo. the apples CLIT.DO I.take later 'The apples, I'll take them later.'

(8) Le prendo dopo le mele. CLIT.DO I.take later the apples 'I'll take them later, the apples.'

Since our aim is to analyze the functional competition of placing a certain marker (in this case, an agreement marker such as a clitic) either on the verbal head or on the nominal dependent, it is necessary to examine the supplementary conjugation rather than the complementary conjugation, since in the latter the dependent noun phrase is absent by definition. Moreover, in the domain of dislocations, left-dislocations are more appropriate than rightdislocations to show phenomena of head marking. This cannot be seen clearly with the dislocated direct objects in (7) and (8), which present the same morphological marking in left-dislocations as in right-dislocations, and differ only in word order. The difference in marking between these two types of dislocations, however, is evident when the extraposed noun phrase is an indirect object, as in (9) and (10):

(9) La Silvana la spesa gliela porto io the Silvana the groceries CLIT.IO-CLIT.DO I.take I 'Silvana, I'll take the groceries to her.'

\footnotetext{
${ }^{2}$ The examples of head marking in (7), (9), and (11)-(14) are drawn from my corpus of the covert recording of conversations held at the grocery store of a village (Orciatico) in the countryside of Pisa, and represent instances of the Tuscan variety of Colloquial Italian. Their dependent-marked or double-marked correspondents in (8), (10), (15) -(26) have been built first on the basis of my native knowledge of Tuscan, and have then been tested for acceptability on informants of the same village.
} 
(10)

\begin{tabular}{|c|c|c|c|}
\hline gliela & porto io & la spesa & alla Silvana \\
\hline CLIT.IO-CLIT.DO & I.take I & the groceries & to.the Silvana \\
\hline
\end{tabular}

In left-dislocations, the extraposed indirect object may appear in its bare form, as can be seen in the sequence la Silvana ... gliela in (9). Instead, in right-dislocations, the preposition necessarily appears in front of the dislocated noun phrase, as in the sequence gliela ... alla Silvana in (10). Only the former clause is a bonafide instance of headmarking. The latter represents, rather, an example of double marking, since the relation of indirect object is expressed both on the dislocated noun phrase (alla Silvana) and on the clitic (gliela, a complex structure consisting of the clitic indirect object $g l i+$ the clitic direct object $l a$ with phonological readjustment). ${ }^{3}$

\section{The topical function of head marking}

The head-marked constructions that we have identified in Italian leftdislocations may play various roles, such as direct object (7), indirect object (9), comitative (11), instrumental (12), and locative (13). It is also found within the noun phrase (14).

(11) La Lina ci vanno d'accordo tutti.
the Lina CLIT.COM get along
'Lina, everybody gets along with her.'
(12) Quest'ombrello mi ci riparo bene.
this umbrella me CLIT.INSTR I.protect well
'This umbrella, I am well protected with it.'
(13) Questa borsa mettici le patate.
this bag put.CLIT.LOC the potatoes
'This bag, put the potatoes in it.'

\footnotetext{
${ }^{3}$ It must be pointed out that left-dislocations may exhibit double marking too: for example, a double-marked construction such as Alla Silvana la spesa gliela porto io is equally acceptable. The point, however, is that the bare expression of the dislocated noun phrase as in (9) is possible - and even more common than double marking - for left-dislocations, while it is impossible for right-dislocations. For a discussion of right-dislocation in Italian, cf. Berruto (1986), Berretta (1995), Sala Gallini (1996), Simone (1997), Rossi (1999).
} 


\section{(14) Renzo, il su' $b a b b o^{4}$ \\ Renzo the POSS dad \\ 'Renzo's dad'}

The subject function has not been included in the examples here because it is absent in the regional variety from which these examples were recorded. ${ }^{5}$ However, the headmarked constructions based on direct objects such as (7) present the same properties of topicality as the left-dislocations with clitic subjects that have been described, for example, for English and French (cf. Donati 1987; Lambrecht 1981). Duranti \& Ochs (1979) show that left-dislocated objects in Colloquial Italian are more similar to prototypical subjects than to prototypical objects. Like subjects, leftdislocated objects are definite and refer to the discourse topic. This may suggest an incipient object agreement on the verb, as argued in Berretta (1995). The grammaticalization of pronouns coreferent with definite and topical objects into authentic object markers is common cross-linguistically. In Swahili, for example, only definite nouns referring to humans trigger verbal agreement with the object (Wald 1979). In Italian, this is especially visible in the periphrastic past (passato prossimo, trapassato prossimo) and in the periphrastic future (futuro anteriore), where the past participle may be inflected for gender and number. As illustrated in Nocentini (2003), a clause with left-dislocation such as I giornali li ho letti 'The newspapers, I read them' exhibits verbal agreement with the dislocated object and with the clitic. The same occurs in a clause with right dislocation such as $\boldsymbol{L} \boldsymbol{i}$ ho letti $\boldsymbol{i}$

\footnotetext{
${ }^{4}$ While head marking in the clause is common with both human and non-human referents, to the extent that they are definite in their context, in the noun phrase head marking is used with human possessors, especially when involved in kinship relations. Renzo, il su' babbo is more acceptable than ?La macchina, le su' rote 'the car, its wheels'. The comma in (14) represents the pause in intonation between the possessor and the possessee. By contrast, head marking in the verb phrase often shows continuous intonation between the extraposed noun and the verb plus clitic constituent in Tuscan.

5 The diffusion of dislocation with a clitic subject is more restricted than that of other roles: it is especially diffused in the Northern Italian dialects (that is, in the dialects spoken above the so-called 'La Spezia-Rimini line' running through Northern Italy from the cities of La Spezia to Rimini), although it can be also found in some Tuscan varieties such as Florentine. Cf. Spiess (1956), Kuen (1957), Brandi \& Cordin (1981), Renzi \& Vanelli (1983), Benincà (1986).
} 
giornali 'I read them, the newspapers'. Instead, in the basic transitive clause Ho letto $i$ giornali 'I read the newspapers', where the object is not topicalized, verbal agreement does not appear (for the absence of verbal agreement with non-topical subjects in the Tuscan dialect, cf. Nocentini 1999).

Similar considerations hold true for oblique roles such as indirect objects, comitative, instrumental, and locative. The extraposed noun phrase in (9) and in (11)-(14) plays the function of the topic in that it represents the piece of information that the clause is about, and is considered by the speaker to be recoverable from the hearer's point of view. In most cases, the extraposed noun phrase refers to an item that was mentioned in some previous nonimmediately adjacent stretch of discourse (if it were contiguous, the referent would have been denoted by a simple clitic without a fully-fledged noun phrase). This occurs in (11) la Lina ci vanno d'accordo tutti, where la Lina was already mentioned in the previous turns of the conversation. In other cases, the referent of the extraposed noun phrase was physically present in the immediate speech situation, as in (12) Quest'ombrello mi ci riparo bene and (13) Questa borsa mettici le patate, where the speaker was actually holding an umbrella and a bag. Sometimes the noun phrase referred to by the clitic can be inferred and accommodated in the conversation by a part-whole relationship or through the background knowledge of the speech act participants. In (9) La Silvana la spesa gliela porto io and in (14) Renzo, il $s u$ 'babbo, for example, the referents of la Silvana and of Renzo were neither previously mentioned nor actually present at the time of utterance, but could nevertheless be easily identified so long as they were part of knowledge shared by the inhabitants of the village.

\section{The focal function of dependent marking}

The topical function of head marking discussed in the previous section is especially clear when compared with noun phrases expressing the focus, that is, the piece of information that the speaker assumes as not being currently activated in the consciousness of the hearer (Chafe 1976; Lambrecht 1994). Although focused noun phrases may occupy the left periphery of the clause like topical noun phrases, they never appear in the bare form, and they never trigger cliticization. Accordingly, they can represent neither head marking nor double marking, but only dependent marking. If we want to express the 
same propositional content as examples (7), (9) and (11)-(14) with a focused complement, examples (15)-(20) are obtained. The accent here signals a pitch deviation accompanied by loudness and lengthening.

(15) Le méle prendo dopo. 'The ápples I'll take later.'

(16) Alla Silvána porto la spesa. 'To Silvána I'll take the groceries.'

(17) Con la Lína vanno d'accordo tutti. 'With Lína everybody gets along.'

(18) Con quest'ombréllo mi riparo bene. 'With this umbrélla I am well protected.'

(19) In questa bórsa metti le patate. 'In this bág put the potatoes.'

(20) Il babbo di Rénzo

'The father of Rénzo'

These constructions manifest instances of the so-called identificational focus, in Kiss's (1998) terms. That is, the referent of the fronted constituent identifies one member of a set of potentially relevant items that could satisfy the predication. As Kiss observes, the identificational focus is not necessarily new information, but always has a strong contrastive function, at least in the Romance languages. The fronted direct object le mele in the clause Le mele prendo dopo (15) entails that the speaker is not taking pears, for example, or other types of fruit. The fronted comitative Con la Lina in the clause Con la Lina vanno daccordo tutti (17) entails that people do not get along with someone else. The same occurs for the dependent-marked possessive construction il babbo di Renzo (20), which may be contrasted with the father of someone else; instead, in head-marked possession such as Renzo, il su' babbo (14) a contrastive implication is not available. A paraphrasis of the constructions (15)-(19) can be achieved by means of clefts or pseudo-clefts, which are normally used to express contrast in Italian.

In the same vein, only dependent-marked constructions may appear in what Kiss (1998) calls information focus. This situation occurs when the focus conveys the new piece of information of the clause without implying any particular contrastive meaning. The information focus is rendered in Italian by placing complements or adjuncts after the verb, in (S)VOX sentences, as in (21)-(26). 
(21) Dopo prendo le méle.

'Later I'll take the ápples.'

(22) Porto la spesa alla Silvána.

'I'll take the groceries to Silvána.'

(23) Tutti vanno d'accordo con la Lína.

'Everybody gets along with Lína.'

(24) Mi riparo bene con quest'ombréllo.

'I am well protected with this umbrélla.'

(25) Metti le patate in questa bórsa.

'Put the potatoes in this bág.'

(26) Il babbo di Rénzo.

'The father of Rénzo'

According to the Nuclear Stress Rule, the clause accent is subjected to 'focus projection', whereby the rightmost word-level stress of a phrase carries the main stress of such a phrase as well as of all other syntactic projections of it (Chomsky \& Halle 1968). For example, in a clause such as Dopo prendo le méle in (21), the focus could be represented not only by the object noun phrase le mele 'the apples' (in response to a wh-question such as Cosa prendi dopo? 'What are you going to take later?'), but also by the verbal phrase Prendo le mele 'I'll take the apples' (in response to a whquestion such as Cosa fai dopo? 'What are you going to do later?'), as well as by the entire sentence. The clause is pronounced with the main stress on the noun mele in all these cases, despite the different scope that the focus may have. For simplicity's sake, in examples (21)-(26) we have indicated in bold only the lowest phrase in the scope of the focus, but the result does not change: differently from right-dislocations such as (10), clitic resumptives are absent from all functional projections.

\section{Functional motivations of head and dependent marking}

Dependent marking is an instance of direct marking, in the terminology of Mallinson \& Blake (1981: 41ff), since the functions of direct object, indirect object, comitative, etc. are directly marked on the noun phrases which represent those functions. This is expected and does not require further comments. Conversely, head marking represents indirect marking, which implies that the function of a noun phrase is marked elsewhere. The reason for this is not obvious and requires an explanation. 
Left-dislocation with head marking exhibits an anomalous structure as compared to the basic transitive clause, especially when the extraposed noun phrase has functions other than direct object. Under normal conditions, the function of indirect object, comitative, instrumental, locative, and possessor is indicated by a preposition, but in the recordings the extraposed noun phrase had a bare form. ${ }^{6}$ The different clitics $g l i$ (IO), $c i$ (LOC), su' (POSS), etc. indicate the syntactic function of the extraposed noun phrase. By indexing the functions of indirect object, comitative, instrumental, and locative on the verb, and the function of the possessor on the head noun, clitics recover the information which has been lost due to aberrant word order and aberrant absence of markers of dependency.

The fact that topicalized noun phrases and focused noun phrases commonly exhibit a bare structure and a dependent-marked structure, respectively, may explain why the process of so-called headward migration is unidirectional. Markers of grammatical relations migrate away from dependents toward the head, but not vice versa. Nichols (1986: 85) denies that linear adjacency is the primary factor for such a migration. Words may jump over intervening constituents toward the head, as in the English clause I only work at home in the evening as compared to the clause I work at home only in the evening. "What is now needed is a positive understanding of the mechanics and motivation of the processes which turn words into affixes" (Nichols 1986: 85). In the pragmatic perspective here adopted, a motivation may exist for the migration of markers toward the head, since in this way the speaker recovers the syntactic function of the extraposed bare constituent. Instead, a migration of markers from head to dependent does not seem to provide a plausible motivation in terms of processing devices.

The use of dependent-marked constructions for focused information may be related to the fact that the focus represents the most salient piece of information for the clause to be informative. By contrast, the topic can often be omitted (and indeed is omitted, if no factor of discontinuity or contrast

\footnotetext{
${ }^{6}$ Interestingly, after they were shown these examples, some informants corrected them with more grammatical forms with prepositions, i.e. with double-marked structures. A speaker, for example, insisted that she had not said La Silvana la spesa gliela porto io (9), but rather Alla Silvana la spesa gliela porto io, with the regular preposition $a$ 'to'. Evidently, the pressure of the standard language was such that the speakers did not recognize the very same structures they had pronounced. This is a manifestation of the difference between spontaneous conversation and elicited sentences.
} 
intervenes). This informational salience manifests itself in a higher pitch accent that the focus typically has (cf. Katamba 1989: 248-250; Selkirk 1995). The same applies to contrastive information; as Chafe (1976: 35) notes, "How is contrastiveness expressed? The principal manifestation is the placement of higher pitch and stronger stress on the focus of contrast. Thus, it is often difficult or impossible to tell the difference between contrast and new information on a phonetic basis alone". Owing to this accentual prominence, a focused constituent maintains its morphological structure more easily than a topical constituent, which tends to be cliticized synchronically and eroded diachronically. It may be hypothesized that a stronger accentuation and, consequently, a more robust morphology has allowed focused constituents to attract relational markers of agreement or dependency more easily than topical constituents.

\section{Sociolinguistic and discoursal properties of head and dependent marking}

Dislocations are widely 'acceptable' (i.e. common in use) in the entire Romance domain, and most likely can be traced back to Vulgar Latin (cf. Durante 1981: 61; Matthews 1989). However, they are not always 'grammatical' (i.e. tolerated in the grammatical tradition of the written, formal language). They are perfectly grammatical, for example, in Romanian: Merele le-a cumpărat Ana 'The apples, Ann bought them' (Mallinson 1988: 409). In Spanish, though, they are grammatical only in certain contexts, particularly with human referents: la vi a Juana 'Johanna, I saw her' (Green 1988: 107). ${ }^{7}$ In Italian, meanwhile, they are stigmatized (Vincent 1988: 290; Posner 1996: 168-169). The examples quoted above would be considered to be mistakes if written in a school composition, and for this reason we resorted to expressions of a regional variety, which is less

\footnotetext{
${ }^{7}$ Structurally, clitics appear as instances of double marking in Spanish, where the function of direct object is encoded by both the clitic and the preposition. This is related to the use of prepositions with object nouns referring to humans in Spanish, as well as in many other languages. Romanian exhibits head marking, like Italian, with object nouns referring to non-humans, and double marking with object nouns referring to humans, like Spanish. In this case, Romanian uses the preposition pe; e.g. pe Radu l-a văzut Maria 'Maria saw Radu' (lit. 'Radu, Maria saw her').
} 
influenced by the standard. French behaves like Italian in this respect, as observed by Bossong (1981) and Gossen (1992), among others.

The tendency to reject dislocations in the written variety of Italian may be related to the fact that these constructions present information in a less straightforward or more redundant manner with respect to their corresponding dependent-marked structures. As mentioned above, headmarked sentences such as left-dislocations involve an indirect type of marking, in the sense that a syntactic relation is expressed where logically it should not be. In the same way, the double marking of right-dislocations contains unnecessary information, since the same syntactic relation is marked on the verb and on the extraposed noun. Considerations of clarity and economy have more weight in formal than in informal language. This is not limited to dislocations, and can be seen in various areas of grammar. Proper names, for example, do not take the definite article in Standard Italian, since definiteness is already implied in proper names and does not need to be overtly expressed. In Non-Standard Italian, however, the definite article with proper names is rather common (in Tuscan, with proper names of females only; in the North, also with males). The same occurs in Hungarian (Rounds 2001: 82). It seems that, if a language allows the use of proper names with or without the definite article, the presence of the article is found in the less standard variety.

Moreover, since pronouns and fully-fledged nouns represent typical sources of head marking and dependent marking respectively (Nichols 1986: 75), it is conceivable that head marking more naturally arises in the spoken informal language, to the extent that in this domain pronouns are more often used than nouns. In the spoken language between intimate acquaintances, the speaker and the hearer share the same physical environment and the same basic experiences, so that a referent is often identifiable without explicit mention. The less that is shared by the speech act participants, the more compelling the unambiguous use of a noun becomes. In spoken formal language, as well as in the written language, the addressee is not assumed to be familiar with the objects of the discourse, which therefore require overt reference.

In both speaking and writing the use or nonuse of pronouns depends in a fundamental way on taking account of the consciousness of the language receiver, whether that person is a listener or a reader. A pronoun is minimally informative, and whereas it might be all that a protagonist-oriented 
consciousness would require (since the reference is already known to the protagonist), very often a pronoun would not satisfy the needs of a reader. (Chafe 1994: 287)

The written formal register, where nouns are more frequent than pronouns, presents fewer opportunities for head marking to emerge.

It is commonly assumed that left-dislocations enable the use of a certain word order freedom in languages, such as Italian or French, in which SVO is the basic word order (cf. Bally 1932). In French, the spread of dislocations (and particularly of right-dislocations) has been related to the emergence of a verb-initial (VSO) word order (Harris 1978; for discussion and criticism, cf. Ashby 1982 and Matthews 1989). In Italian, this word order freedom seems to be especially exploited as a means of organizing sentences around a nonagent role. We may argue that the use of head-marked structures in the spoken or informal variety is equivalent to the use of the passive in the written or formal variety. While a basic active clause such as (27) is commonly used when the agent outranks the patient in topicality, the passive in (28) and the head-marked clause in (29) are patient-oriented patterns, and share the same pragmatic function of a topical patient and a focal agent.

(27) Adriano ha piantato i fiori.

'Adriano planted the flowers.'

(28) I fiori sono stati piantati da Adriano.

'The flowers have been planted by Adriano.'

(29) I fiori li ha piantati Adriano. 'The flowers, Adriano planted them.'

The active clause in (27), characterized by the regular VO order, can be considered as being a statement about the subject, and represents a satisfactory answer to the question 'What did Adriano plant?', if the focus is restricted to the object; or to the question 'What did Adriano do?', with broad focus on the verb phrase. Instead, the passive in (28) and the headmarked clause in (29) are assertions about the flowers, which tend to be interpreted as given information. The corresponding questions in these cases would be 'Who planted the flowers?', with narrow focus, or 'What happened to the flowers?', with broad focus. Accordingly, head-marked constructions seem to represent a type of inverse voice which has been labelled as 'foregrounding passive' (Foley \& Van Valin 1985: 306ff) or 'promotional passive' (Givón 2001: II, 127ff), since they promote a non-agent without 
demoting the agent (while the cross-linguistically more common type of passive is agentless).

\section{Cross-linguistic parallels}

The suggested association in non-standard Italian between head marking and topicalization on the one hand, and between dependent marking and focalization on the other, is supported by cross-linguistically recurrent cases of split marking. When the same language uses head marking for some constructions and dependent marking for others, head marking usually extends to those domains where topicalization is more typical than focalization. Conversely, in the typical domains of focalization, dependent marking commonly appears, both in the noun phrase and in the verb phrase.

In split marking of the noun phrase, while head marking is favoured with pronouns, dependent marking appears with overt nouns, especially when modified by adjectives and relative clauses (Nichols 1986: 75). It is acknowledged that fully-fledged nouns are related to high text discontinuity, which implies the introduction of new information (Givón 1983). When split marking is within the category of nouns, head marking is found with nouns with human referents, which of course are more typical candidates for topic status than inanimate referents. English possessive phrases provide a clear example of this. According to an account made popular by Janda (1980; see also Vezzosi 2000), the Modern English possessive genitive John's book derives from the reanalysis of a genitive morpheme into a head-marked structure such as John, his-book, and is mostly used with human referents (Hawkins 1981; Kreyer 2003; Rosenbach 2005) which represent old information (Altenberg 1980; Deane 1987; Standwell 1990; Anschutz 1997). By contrast, the dependent-marked of-construction is used with inanimate referents which represent new information.

Possessive phrases often exhibit head marking with inalienable possession, and dependent marking with alienable possession (Nichols 1992: 116-122). This also occurs in some Italian dialects, especially in Southern Italy, where possessive pronouns may be enclitic only to kinship terms (e.g. frátu-ta 'your brother') and to the name of the 'house' (e.g. cász-ta 'your house'; cf. Rohlfs 1968: 124ff). Inalienable possessees such as kin or body parts are relational nouns, which more often require the explicit mention of their possessor in the discourse, and which therefore have a greater chance 
of developing a tighter structural linkage with it. It may be argued that an inalienable possessee is not used to denote a referent, but rather to describe the possessor by means of an inherent property of his, so that the possessor, rather than the possessee, is contextually the topic of the discourse.

One could object that the possessor of an inalienable possession construction is not necessarily the discourse topic. For example, if I want to talk about Mary's father, it may be that the father is the topic of the discourse and not necessarily Mary. This, however, applies only to kinship terms, and not to body part nouns, which clearly are unlikely to be the topic of a discourse. Body part nouns usually have the function of patients or instruments in the discourse. Thus, there is a consistent class of lexemes such as body parts that regularly appear in constructions where the possessor is more topical than the possessee. This is especially evident in Romance languages such as Italian and French, which may encode the notional possessor as the subject of a 'be'-clause only in case of inalienable possession with body part nouns:

Je puis dire de Sylvie qu'elle est belle de taille, noire de cheveux, longue de cils, fine de doigts, bien faite des jambes; pourquoi ma conscience linguistique se cabre-t-elle devant belle de gants, noire de chaussure, longue de manches, fine d'étoffe, bien faite des vêtements? Pour que la conversion soit possible, les deux sujets logiques doivent être conçus comme formant une seule et même substance. Au contraire de la taille, des cheveux, des cils, des doigts, des jambes, qui font partie intégrante de Sylvie, les gants, la chaussure, les manches, l'étoffe, les vêtements sont extérieurs à la personne. (Frei 1939: 188)

In some languages of the Amazon, where possessive phrases are typically head marked, the verb agrees in grammatical gender with the possessee in alienable possession, but with the possessor in inalienable possession. In Yarawara, in the alienable construction corresponding to 'It is Wero's (M) cassava meal (F)', the verb is marked for feminine gender like the possessee 'cassava meal' and unlike the possessor 'Wero'. By contrast, in the inalienable construction corresponding to 'It is the voice (F) of Okomobi (M)', the verb is marked for masculine gender like the possessor 'Okomobi' and unlike the possessee 'voice'. Everett (2006) interprets this possessive system, which is at odds with traditional endocentric constituent structure, as a manifestation of the fact that in inalienable possession the discourse is about the possessor rather than the possessee. 
When split marking involves the verb phrase, head marking appears not only in the agreement of the verb with the subject and with the object, which represent the primary and the secondary topic of the clause (Givón 1984), but also in the applicative structures that characterize polysynthetic languages. Applicatives increase verb valence, so that a participant having the role of beneficiary, instrument, location, etc. becomes a core argument. Speakers choose the synthetic strategy of applicatives when they want to represent a situation in a single clause, rather than in separate sentences (Mithun 2001). Since one clause typically contains only one chunk of new information at a time, multiple chunks of information may be packaged in a single clause only if some of them are already known. Applicatives may also be preferred to an oblique or prepositional strategy when the referent is a discourse topic and plays a prominent role in the text (Donohue 2001). Typical dependent-marked constructions such as prepositions may involve the same participants as applicative structures, and still often encode pieces of new, focused information. Prepositions represent a common source for markers of clause chaining. According to Nichols (1986: 75), clause chaining is the most typical dependent-marked construction in languages. It is also a favoured conduit to impart new information in discourse (Givón 2001: II, 356ff).

It seems that the grammar of head marking and of dependent marking is shaped by competing processes of discourse cohesion. Head marking grammaticalizes the tendency to anchor a referent to given or accessible information, which is related to human, specific, or definite referents. Dependent marking grammaticalizes the tendency to move the narration along, by introducing lexical noun phrases which represent a new piece of information, and which mainly denote inanimate, generic, or indefinite referents.

The loose, appositive linkage implied in head marking also matches the usage of this structure in pidgins (Nichols 1986: 105-106). If a different type of marking appears in a pidgin and in its related creole, the latter is likely to develop dependent-marked constructions. Besides the contrast between spoken informal language and written formal language, the contrast between pidgin and creole is a further manifestation of the pragmatic mode vs. syntactic mode as outlined by Givón (1979: 263). Alternatively, if a different type of marking appears in a language and in its related creole or colonial variety, the latter is likely to exhibit a more pronounced degree of head marking. This can be seen in Afrikaans, where the possessive linker se is 
originally a non-emphatic form of $s y(n)$ going back to Dutch $z i j n / z$ 'n 'his': Piet se vrou 'Piet's wife', Suid-Afrika se hoofstad 'South Africa's capital' (Donaldson 1994: 500-501). In Dutch, head-marked constructions such as Loek z'n vader 'Luke's father' also appear, but they are regarded as less formal than the corresponding dependent-marked constructions such as de vader van Loek 'the father of Luke'. In English, the etymologically headmarked $s$-genitive is perfectly grammatical, yet it is acknowledged as having a lower register than the dependent-marked of-construction: "The ofconstruction is on the whole more readily accepted in formal or elevated style" (Altenberg 1980: 170).

\section{Conclusions}

We have seen that, when the same language represents the same syntactic relation with either head marking or dependent marking, these constructions do not express the same pragmatic implications. Head marking expresses topical information, while focused information is favoured in dependent marking. These pragmatic functions, which emerge in certain phenomena of cliticization of Colloquial Italian, are cross-linguistically confirmed by phenomena of split marking.

Although various scholars have already stated that certain structures such as dislocations are instances of topicalization and are mainly used in nonstandard linguistic varieties, it has been not adequately stressed that the topical function and the informal register are pervasive properties of head marking in general, both in the clause and in the noun phrase. Particularly, it has not been observed so far that a connection may exist between the form of dependent marking and the function of focus.

We have identified some possible motivations for this connection, which ultimately have to do with the phonological correlates of topic and focus. When the complement is topicalized, the head represents the focus and therefore exhibits a higher pitch, which tends to attract the relational markers: the resulting structure will be head marking. Instead, when the complement represents the focus of the clause, it will have a stronger accentuation than that of the head, with the consequent attraction of the relational particles: in this case we have dependent marking.

The fact that head marking may appear in the informal variety of an otherwise dependent-marking language may indicate that the similarities 
among languages may become more patent if we move from the syntactic level, where the distinction between head and dependent marking properly belongs, to the semantic and pragmatic levels, which are more evident in colloquial style. The clear-cut distinction between head and dependent marking can sometimes be attributed to the fact that most reference grammars focus on structural phenomena but are often silent on discourse strategies and on sociolinguistic nuances.

\begin{abstract}
Abbreviations
CLIT $=$ clitic $;$ COM $=$ comitative $;$ DAT $=$ dative $;$ DEM $=$ demonstrative $;$ DO $=$ direct object; $\mathrm{ERG}=$ ergative $; \mathrm{F}=$ feminine; $\mathrm{GEN}=$ genitive; INSTR = instrumental; $\mathrm{IO}=$ indirect object; $\mathrm{LOC}=$ locative $; \mathrm{M}=$ masculine; $\mathrm{NOM}=$ nominative; $\mathrm{OBL}=$ oblique; POSS $=$ possessive.
\end{abstract}

\title{
References
}

Altenberg, Bengt. 1980. Binominal NPs in a thematic perspective: Genitive vs. ofconstruction in 17th century English. In Sven Jacobson, ed. Papers from the Scandinavian Symposium on syntactic variation. Stockholm: Almqvist \& Wiksell, 149-172.

Anschutz, Arlea. 1997. How to choose a possessive noun phrase construction in four easy steps. Studies in Language 21: 1-35.

Ashby, William J. 1977. Clitic inflection in French: A historical perspective. Amsterdam: Rodopi.

Ashby, William J. 1982. The drift of French syntax. Lingua 57: 29-46.

Bally, Charles. 1932. Linguistique générale et linguistique française. Paris: Leroux.

Benincà, Paola. 1986. Punti di sintassi comparata dei dialetti italiani settentrionali. In Günter Holtus \& Kurt Ringger, eds. Raetia antiqua et moderna. Tübingen: Niemeyer, 457-478.

Berretta, Monica. 1995. Ordini marcati dei costituenti maggiori di frase: una rassegna. Linguistica e Filologia 1: 125-170.

Berruto, Gaetano. 1986. Le dislocazioni a destra in italiano. In Harro Stammerjohann, ed. Tema-Rema in italiano. Tübingen: Narr, 55-69.

Bossong, Georg. 1981. Séquence et visée. Folia Linguistica 15: 237-252.

Brandi, Patricia \& Lucia Cordin. 1981. Dialetti e italiano: un confronto sul parametro del soggetto nullo. Rivista di Grammatica Generativa 6: 33-87.

Chafe, Wallace. 1976. Givenness, contrastiveness, definiteness, subjects, topics, and point of view. In Li, ed. 25-55. 
Chafe, Wallace. 1994. Discourse, consciousness, and time. Chicago \& London: The University of Chicago Press.

Chomsky, Noam \& Morris Halle. 1968. The sound pattern of English. New York: Harper \& Row.

Cysouw, Michael. 2002. Interpreting typological clusters. Linguistic Typology 6: 69-93.

Deane, Paul. 1987. English possessives, topicality, and the Silverstein hierarchy. In Proceedings of the Thirteenth Annual Meeting of the Berkeley Linguistics Society. Berkeley, CA: Berkeley Linguistics Society, 65-76.

Donaldson, Bruce. 1994. Afrikaans. In Ekkehard König \& Johan van der Auwera, eds. The Germanic languages. London \& New York: Routledge, 478-504.

Donati, Antonella. 1987. Costruzioni con tema marcato in inglese: le dislocazioni a sinistra. Florence: University of Florence MA Dissertation.

Donohue, Mark. 2001. Coding choices in argument structure: Austronesian applicatives in texts. Studies in Language 25: 217-254.

Durante, Marcello. 1981. Dal latino all'italiano moderno. Bologna: Zanichelli.

Duranti, Alessandro \& Elinor Ochs. 1979. Left dislocation in Italian conversation. In Givón, ed. 377-416.

Everett, Daniel. 2006. Non-endocentric syntax in Amazonian languages: Problems for theories of phrase structure. Paper presented at the Leipzig Spring School in Linguistic Diversity (March 20-28, 2006), Max Planck Institute for Evolutionary Anthropology.

Frei, Henri. 1939. Sylvie est jolie des yeux. In Mélanges de linguistique offerts à Charles Bally sous les auspices de la Faculté des lettres de l'Université de Genève par des collègues, des confrères, des disciples reconnaissants. Genève: Georg.

Foley, William A. \& Robert D. Van Valin, Jr. 1985. Information packaging in the clause. In Timothy Shopen, ed. Language typology and syntactic description. Vol. 1: Clause structure. Cambridge: Cambridge University Press, 282-364.

Givón, Talmy. 1976. Topic, pronoun and grammatical agreement. In Li, ed. 149188.

Givón, Talmy. 1979. On understanding grammar. New York: Academic Press.

Givón, Talmy, ed. 1979. Syntax and semantics. Vol. 12: Discourse and syntax. New York: Academic Press.

Givón, Talmy. 1983. Topic continuity in discourse: An introduction. In Talmy Givón, ed. Topic continuity in discourse. Amsterdam: Benjamins, 3-41.

Givón, Talmy. 1984. Direct object and dative shifting: Semantic and pragmatic case. In Frans Plank, ed. Objects. Toward a theory of grammatical relations. New York: Academic Press, 151-182.

Givón, Talmy. 2001. Syntax. An Introduction. 2nd edition. Amsterdam: Benjamins. 
Gossen, Carl Theodore. 1992. Quelques aspects de la mise en relief d'une idée en italien et en français. Zeitschrift für romanische Philologie 67: 147-166.

Green, John N. 1988. Spanish. In Harris \& Vincent, eds. 79-130.

Harris, Martin. 1978. The evolution of French syntax: A comparative approach. London: Longman.

Harris, Martin \& Nigel Vincent, eds. 1988. The Romance languages. New York: Oxford University Press.

Hawkins, Roger. 1981. Towards an account of the possessive constructions: NP's N and the N of NP. Journal of Linguistics 17: 247-269.

Helmbrecht, Johannes. 2001. Head-marking vs. dependent-marking languages. In Martin Haspelmath, Ekkehard König, Wulf Oesterreicher \& Wolfgang Raible, eds. Language typology and language universals. An international handbook. Berlin: Mouton de Gruyter, Vol. 2: 1424-1432.

Janda, Richard D. 1980. On the decline of declensional systems: The overall loss of OE nominal case inflections and the ME reanalysis of -es as his. In Elizabeth Closs Traugott, Rebecca Labrum \& Susan Shepherd, eds. Papers from the Fourth International Conference on Historical Linguistics. Amsterdam: Benjamins, 243-253.

Katamba, Francis. 1989. An introduction to phonology. London \& New York: Longman.

Kiss, Katalin É. 1998. Identificational focus versus information focus. Language 74: 245-273.

Kreyer, Rolf. 2003. Genitive and of-construction in modern written English: Processability and human involvement. International Journal of Corpus Linguistics 8: 169-207.

Kuen, Heinz. 1957. Die Gewohnheit der mehrfachen Bezeichnung des Subjekt in der Romania und die Gründe ihres Aufkommens. In Günter Reichenkron, ed. Syntactica und Stylistica: Festschrift für Ernstl Gamillscheg zum 70. Geburtstag. Tübingen: Niemeyer, 293-326.

Lambrecht, Knud. 1981. Topic, antitopic and verb agreement in Non-Standard French. Amsterdam: Benjamins.

Lambrecht, Knud. 1994. Information structure and sentence form. Topic, focus and the mental representations of discourse referents. Cambridge: Cambridge University Press.

Li, Charles N., ed. Subject and topic. New York: Academic Press.

Mallinson, Graham. 1988. Rumanian. In Harris \& Vincent, eds. 391-419.

Mallinson, Graham \& Barry J. Blake. 1981. Language typology. Cross-linguistic studies in syntax. Amsterdam \& New York: North Holland Publishing Company. 
Matthews, Stephen J. 1989. French in flux: Typological shift and sociolinguistic variation. In Thomas J. Walsh, ed. Synchronic and diachronic approaches to linguistic variation and change. Washington, DC: Georgetown University Press, 188-203.

Mithun, Marianne. 2001. Understanding and explaining applicatives. In Mary Andronis, Christopher Ball, Heidi Elston \& Sylvain Neuvel, eds. Proceedings from the Parasessions of the Thirthy-Seventh Meeting of the Chicago Linguistic Society: Functionalism and formalism in linguistic theory. Chicago: Chicago Linguistic Society, Vol. 37.2: 73-98.

Nichols, Johanna. 1986. Head-marking and dependent-marking grammar. Language 62: 56-119.

Nichols, Johanna. 1992. Linguistic diversity in space and time. Chicago: The University of Chicago Press.

Nocentini, Alberto. 1999. Topical constraints in the verbal agreement of spoken Italian (Tuscan variety). Rivista di Linguistica 11: 315-339.

Nocentini, Alberto. 2003. The object clitic pronoun in Italian: A functional interpretation. In Giuliana Fiorentino, ed. Romance objects: Transitivity in the Romance languages. Berlin: Mouton de Gruyter, 105-116.

Posner, Rebecca. 1996. The Romance languages. Cambridge: Cambridge University Press.

Renzi, Lorenzo \& Laura Vanelli. 1983. Il pronome soggetto in alcune varietà romanze. In Scritti linguistici in onore di Giovan Battista Pellegrini. Pisa: Pacini, Vol. 1: 121-145.

Rohlfs, Gerhard. 1968. Grammatica storica della lingua italiana e dei suoi dialetti. Vol. 2: Morfologia. Torino: Einaudi.

Rosenbach, Anette. 2005. Animacy versus weight as determinants of grammatical variation in English. Language 81: 613-644.

Rossi, Fabio. 1999. Non lo sai che ora è? Alcuni considerazioni sull'intonazione e sul valore pragmatico degli enunciati con dislocazione a destra. Studi di Grammatica Italiana 18: 145-193.

Rounds, Carol. 2001. Hungarian. An essential grammar. London \& New York: Routledge.

Sala Gallini, Mario. 1996. Lo statuto del clitico nella dislocazione a destra: pronome vero o marca flessionale. Archivio Glottologico Italiano 81: 76-94.

Selkirk, Elisabeth. 1995. Sentence prosody: Intonation, stress, and phrasing. In John A. Goldsmith, ed. The handbook of phonological theory. Oxford: Blackwell, $550-569$.

Simone, Raffaele. 1997. Une interprétation diachronique de la «dislocation à droite» dans les langues romanes. Langue Française 115 : 48-61.

Spiess, Federico. 1956. Die Verwendung des Subjekt-Personalpronomens in den lombardischen Mundarten. Bern: Francke. 
Standwell, G. J. B. 1990. Genitive constructions and functional sentence perspective. In Dietrich Nehls, ed. Grammatical studies in the English language. Heidelberg: Julius Groos Verlag, 53-58.

Vincent, Nigel. 1988. Italian. In Harris \& Vincent, eds. 279-313.

Vezzosi, Letizia. 2000. John his book vs. John's book: Possession marking in English. ZAS Papers in Linguistics 15: 168-198.

Wald, Benji. 1979. The development of the Swahili object marker: A study of the interaction of syntax and discourse. In Givón, ed. 505-524.

Author's address

University of Zurich

Klassisch-Philologisches Seminar

Rämistrasse 68

CH-8001 Zürich, Switzerland

received: 23 December 2006

e-mail: carlotta.viti@klphs.uzh.ch

resubmitted: 20 September 2008

revised version accepted: 22 October 2008 